\title{
Infeksi Toxocara canis pada Anjing Lokal di Banyuwangi
}

\section{Toxocara canis Infection in Local Dog at Banyuwangi}

\author{
Rahayu Carlis Savitri ${ }^{*}$, Vivi Oktaviana ${ }^{1}$, Faisal Fikri ${ }^{2}$ \\ ${ }^{1}$ Student of Veterinary Medicine, ${ }^{2}$ Department of Veterinary Science, \\ Faculty of Veterinary Medicine, PSDKU Banyuwangi Universitas Airlangga, \\ Jl. Wijaya Kususma No. 113, Mojopanggung, Giri, Banyuwangi \\ *Corresponding author: rahayu.carlis.savitri-2015@fkh.unair.ac.id
}

\begin{abstract}
Abstrak
Studi kasus ini bertujuan untuk menjelaskan mengenai kasus infeksi penyakit helminthiasis dan siklus hidup parasit pada anjing lokal. Pemeriksaan dilakukan pada feses yang masih segar secara makroskopis dan mikroskopis. Pemeriksaan secara makroskopis dengan mengamati warna, bau, dan konsistensi feses. Pemeriksaan mikroskopis menggunakan uji natif, uji sedimen, dan uji apung. Berdasarkan gejala klinis dan hasil pemeriksaan feses didapatkan hasil bahwa anjing lokal posistif terinfeksi Toxocara canis.
\end{abstract}

Kata kunci: anjing, Toxocara canis, helminthiasis, pemeriksaan feses

\begin{abstract}
This case study aimed to explain the case of helminthiasis infection and life cycle of the parasite in a local dog. Examination performed on faeces that were still fresh macroscopically and microscopically. Macroscopic examination observed the color, smell, and consistency of feces. Microscopic examination performed native test, sediment test, and floatation test. Based on clinical symptoms and the results offecal examination, it was found that the dog was positively infected with the Toxocara canis.
\end{abstract}

Key words: dog, Toxocara canis, helminthiasis, fecal examination

Received: 7 Mei 2019

Revised: 18 Juni 2019

Accepted: 8 Juli 2019

\section{PENDAHULUAN}

Anjing adalah hewan yang sangat dekat dengan manusia. Anjing merupakan hewan kesayangan dengan jumlah ras terbanyak dan memiliki perbedaan antara satu dengan yang lainnya sehingga mendorong manusia untuk memberi perhatian lebih. Selain hewan kesayangan anjing sering juga dimanfaatkan untuk penjaga rumah dan sebagai hewan percobaan. Anjing kampung adalah salah satu jenis anjing yang mampu bersosialisasi dengan manusia dan tidak sulit pemeliharaannya. Anjing kampung belum diketahui pasti asal usulnya karena berasal dari perkawinan silang antar anjing-anjing sehingga menghasilkan ras baru yang umumnya belum teridentifikasi (Dharmojono, 2003).
Berbagai genus nematoda hidup di dalam saluran pencernaan anjing seperti golongan Ascaris (Ascaris sp., Toxocara cati, Toxocara canis dan Toxascaris leonina), Trichuris sp., Capillaria sp., Trichostrongilus sp., Strongylus sp., dan Ancylostoma spp. (Bowman et al., 2003). Cacing ini umumnya menular melalui tanah pada saat anjing beraktivitas dan memperoleh makanan. Berbagai jenis hewan yang menjadi inangnya meliputi hewan ternak, hewan kesayangan, dan satwa liar (Sudhaus dan Fitch, 2001; Arifin dkk., 2019).

Diagnosis klinis terhadap kasus helmintiasis dilakukan berdasarkan pendekatan terhadap gejala klinis yang timbul terutama diare dan evaluasi gambaran fisik feses, sedangkan diagnosis definitif melalui pemeriksaan di laboratorium diambil sebagai langkah lanjutan sesuai prosedur pemeriksaan klinis yang 
berurutan. Dalam dunia praktisi hewan kecil pada khususnya, pemahaman secara komprehensif terhadap pendekatan baik secara klinis maupun laboratoris terhadap kasus helmintiasis merupakan hal yang utama disamping pemahaman lain seperti siklus hidup dan faktor-faktor predisposisi (Samosir, 2008).

Penelitian ini bertujuan untuk menjelaskan infeksi helminthiasis pada anjing lokal beserta siklus hidup parasit melalui pemeriksaan feses dengan metode natif dan apung.

\section{METODE PENELITIAN}

\section{Waktu dan Tempat}

Penelitian dilaksanakan pada bulan Oktober 2018. Sampel feses diperoleh dari anjing peliharaan di wilayah Kecamatan Purwoharjo, Banyuwangi. Pemeriksaan laboratorium untuk deteksi cacing menggunakan metode sederhana natif, sedimen, dan apung di laboratorium Universitas Airlangga, PSDKU Banyuwangi.

\section{Alat dan Bahan}

Bahan yang diperlukan adalah feses, air, aquades dan larutan pengapung (garam jenuh). Alat yang digunakan adalah pot organ, spidol permanen, label nama, pipet, timbangan digital, gelas plastik, saringan teh, sentrifus, mikroskop, tabung reaksi, gelas beaker, gelas obyek dan gelas penutup.

\section{Gejala Klinis}

Anjing lokal bernama Ciko, berwarna coklat hitam, berjenis kelamin jantan, umur 5 tahun, dan berat badan $15.5 \mathrm{~kg}$. Anjing memiliki postur tubuh sedang dengan perut buncit dan tanda klinis diare.

\section{Metode}

Metode yang digunakan untuk mendeteksi infeksi helminthiasis dengan mengambil sampel feses dan dilanjutkan dengan uji laboratorium. Sampel feses diletakkan ke dalam pot sampel dan diberi label berisi nama hewan, jenis kelamin, waktu pengambilan, dan tempat pengambilan. Uji laboratorium yang dilakukan untuk pemeriksaan feses tersebut adalah secara makroskopis dan mikroskopis. Makroskopis adalah dengan melihat warna, bau, dan konsistensi feses. Mikroskopis adalah dengan menggunakan uji natif, uji sedimen, dan uji apung. Feses sebanyak 4 gram dihomogenkan dengan $56 \mathrm{~mL}$ larutan pengapung kemudian disaring beberapa kali. Filtrat dimasukkan ke dalam tabung reaksi sampai larutan membentuk meniscus atas cembung. Kaca penutup diletakkan di filtrat yang telah dibuat. Kaca penutup didiamkan selama 15 menit diatas filtrat. Setelah 15 menit kaca penutup diangkat dan diletakkan di atas gelas obyek, kemudian diperiksa di bawah mikroskop dengan perbesaran 40x dan 100x (Rinaldi et al., 2014).

\section{HASIL DAN PEMBAHASAN}

Hasil pemeriksaan parasitologik pada feses anjing lokal Ciko menunjukkan ada infeksi parasit cacing pada saluran pencernaan. Berdasarkan pemeriksaan feses anjing lokal Ciko dengan uji natif, uji sedimen, dan uji apung menghasilkan positif terinfeksi T. canis.

Telur T. canis mempunyai permukaan dinding berlubang dengan struktur poligonal berbentuk bulat berwarna kecoklatan, permukaannya berbintik-bintik, dinding luar sangat tebal, ukuran telur cacing T. canis $80 \times 75$ $\mu \mathrm{m}$ yang berbentuk oval dengan permukaan bergerigi, berwarna cokelat muda, dan berdinding tebal (Gambar 1) (Koesdarto, 2001).

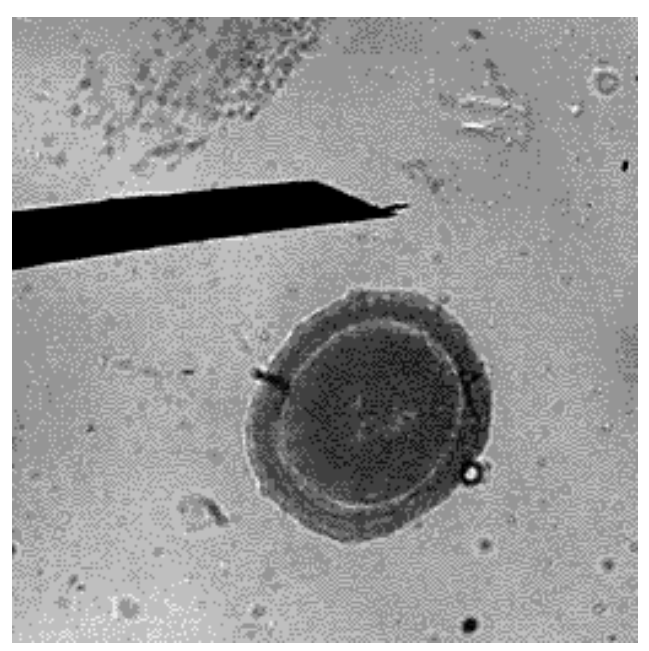

Gambar 1. Hasil pemeriksaan feses T. canis 
Ascariasis merupakan penyakit terpenting dari penyakit cacingan golongan nematoda. Ascariasis yang paling banyak mengakibatkan kerugian pada anjing adalah T. canis (Evayana, 2017). Menurut Sariego et al., (2012) T. canis tidak saja berbahaya bagi hospes, tetapi juga dilaporkan dapat menginfeksi manusia, sehingga tergolong penyakit zoonosis. T. canis sangat merugikan bagi kesehatan hewan maupun kesehatan manusia. Kerugian ditinjau dari sudut ekonomi juga sangat besar, termasuk biaya yang harus dikeluarkan dalam rangka usaha pengendaliannya.

Hasil penelitian prevalensi infeksi $T$. canis pada anjing di Nigeria didapatkan sebesar $31.80 \%$ (Kutdang et al., 2010) di Ethiopia sebesar 26.6\% (Zelalem dan Addis, 2012) dan $32.03 \%$ (Dejene et al., 2013). Sedangkan Thailand sebesar 6.6\% (Wichit et al., 2014). T. canis juga tersebar secara kosmopolit dan ditemukan di Indonesia. Di Jakarta prevalensi $T$. canis sebesar 38.3\% (Taniawati dan Margono, 2008). Infeksi $T$. canis ke anjing menurut (Subronto, 2006) dapat secara langsung, melalui inang paratenik, intra-uteri dan transmamaria. Anak anjing sangat rentan terinfeksi telur infektif $T$. canis karena infeksi sering ditularkan melalui intra-uteri. Pertahanan tubuh menjadi faktor lain yang mempengaruhi infeksi telur infektif ke anak anjing.

Rute infeksi lansung bisa terjadi karena infeksi telur infektif dari lingkungan terhadap anjing. Telur infektif tetap berkembang hingga larva stadium kedua yang kemudian bermigrasi ke jaringan somatik dalam bentuk kista (Suroiyah dkk., 2018). Kista akan berlanjut ke infeksi intrauteri pada anjing betina sedangkan pada anjing jantan kista tidak berkembang. Kista yang bertahan pada jaringan somatik dapat mengakibatkan infeksi secara intrauteri pada anjing yang bunting. Larva akan menembus plasenta dan bermigrasi ke fetus anjing. Saat dilahirkan larva pada anak anjing berada di paru paru (Fatmawati, 2014).

Infeksi melalui inang paratenik terjadi ketika anjing memakan karkas atau daging dari inang paratenik yang telah terinfeksi telur $T$. canis Hewan pengerat merupakan inang paratenik dari
T. canis Telur infektif dari T. canis didalam inang paratenik akan menetas menjadi larva. Daging yang terinfeksi larva tersebut termakan anjing sehingga anjing akan terinfeksi larva infektif $T$. canis yang akan migrasi ke organ organ ditubuh. Transmamaria merupakan jalur infeksi lain dari T. canis Infeksi ini berasal dari ambing (transmamaria) dan plasenta (transplacenta). Infeksi trans mamari bermigrasi melalui penyusuan induk anjing kepada anaknya. Telur $T$. canis menginfeksi kolostrum sehingga menginfeksi anak anjing yang sedang menyusui (Supraptini, 2013).

Menurut Murniati et al., (2016) penderita ascariasis memperlihatkan gejala kelemahan terutama disebabkan oleh anemia yang diderita. Ekspresi muka tampak sayu, mata berair, dan mukosa mata maupun mulutnya tampak pucat serta gejala anoreksia juga sangat mencolok. Migrasi larva juga menyebabkan batuk, dispnoea dan adanya radang paru ringan. Hewan yang mengalami infestasi cacing yang berat dapat menunjukkan gejala kekurusan, rambut kusam, dan gangguan usus yang ditandai dengan sakit perut (colic).

Anjing yang terinfeksi $T$. canis akan memperlihatkan gejala klinis berupa penurunan nafsu makan, gangguan pencernaan berupa diare, dan pembesaran bagian abdominal. Migrasi dari larva cacing ini akan menyebabkan terjadinya kerusakan hati dan paru paru (Foreyt, 2001). Patogenensis dari Toxocariasis tergantung dari banyaknya cacing yang menginfeksi tubuh hewan, umur hewan serta daya tahan tubuh hewan. Pada anjing muda infeksi yang berat dapat menyebabkan obstruksi pada usus dan terjadi perlubangan pada usus sehingga akan menyebabkan terjadinya peritonitis dan kematian. Anjing yang terinfeksi dari T. canis akan terlihat lemah karena mengalami anemia (Subronto, 2006).

Secara umum anjing jantan lebih peka terhadap infeksi parasit cacing dibandingkan dengan anjing betina, hal ini kemungkinan disebabkan karena hormon estrogen pada anjing betina lebih banyak dibandingkan hormon estrogen yang terdapat pada anjing jantan. Hormon estrogen dapat memacu sel-sel RES 
(Reticulo Endhotelial System) untuk membentuk antibody terhadap parasite cacing. Berdasarkan jenis kelamin menunjukkan persentase anjing jantan sebesar $25 \%$ dan anjing betina $18.42 \%$. Di Gondar, Ethiopia prevalensi anjing jantan sebesar $7.7 \%$ dan anjing betina sebesar $7.1 \%$ (Eline et al., 2011).

Penyakit parasit pada anjing memiliki tingkat mortalitas rendah. Infeksi cacing di dalam usus dapat menyebabkan obstruksi pada usus. Namun gangguan ini tidak langsung berakibat fatal pada kematian anjing. Pada anjing dewasa kasus helminthiasis menyebabkan terjadinya penurunan berat badan dan juga terlihat mudah lelah sehingga menurunkan kemampuan dalam berburu (Akhira dkk., 2013).

\section{KESIMPULAN}

Berdasarkan pemeriksaan feses anjing lokal terindetifikasi positif menderita helminthiasis dari spesies T. canis. Pemeriksaan feses untuk mendeteksi endoparasit pada hewan peliharaan adalah upaya untuk mencegah infeksi dan penularan penyakit helminthiasis pada hewan dan zoonosis ke manusia.

\section{UCAPAN TERIMA KASIH}

Penulis mengucapkan terima kasih kepada owner anjing lokal di Kecamatan Purwoharjo, Banyuwangi.

\section{DAFTAR PUSTAKA}

Akhira, D., Fahrimal, Y., Hasan, M. 2013. Identifikasi Parasit Nematoda Saluran Pencernaan Anjing Pemburu (Canis familiaris) Di Kecamatan Lareh Sago Halaban Provinsi Sumatera Barat. J. Med. Vet., 7(1), 42-45.

Arifin, K., Kusnoto, Yudhana, A., Sunarso, A., Purnama, M.T.E., Praja, R.N. 2019. Prevalensi Haemonchiasis Pada Kambing Peranakan Etawah di Kecamatan Kalipuro, Banyuwangi. J. Med. Vet., 2(2), 108-111.
Bowman, D.D., Barr, S.C., Hendrix, C.M., Lindsay, D.S. 2003. Gastro-Intestinal Parasites Of Cats International Vaterinary Information Service Ithaca New York, USA.

CDC. Centers For Disease Control and Prevention. 2013. Parasites Toxocara Canis. Usa: Centers For Disease Control And Prevention.

Dejene, G., Geyola, M., Dagne, E., Asmare, K., Mekuria, S. 2013. Gastrointestinal Helminthes In Dogs And Community Perception On Parasite Zoonosis At Hawassa City, Ethiopia. Glob. Vet., 11(4), 432-440.

Dharmojono. 2003. Anjing Permasalahan Dan Pemecahan. Jakarta: Penebar Swadaya.

Eline, A., Bogale, B., Chanie, M. 2011. Intestinal Nematode Parasite Of Dog: Prevalence And Associated Risk Factors. Department Of Paraclinical Studies, Faculty Of Veterinary Medicine, University Of Gondar, Ethiopia. Acta Parasitol. Glob., $3(2), 28-33$.

Evayana, M., Dwinata, I.M., Puja, I.K. 2017. Prevalensi Infeksi Cacing Toxocara Canis Pada Anjing Kintamani di Desa Sukawana, Kecamatan Kintamani, Kabupaten Bangli, Bali, Indonesia. Med. Vet., 6(2), 115-123.

Fatmawati, D. 2014. Identifikasi Toxocara Canis Pada Anak Anjing di Makassar Pet Clinic [Skripsi]. Makasar, Program Studi Kedokteran Hewan Fakultas Kedokteran, Universitas Hasanuddin. Hal. 7-11.

Foreyt, J. 2001. Veterinary Parasitology : Reference Manual. Usa: Iowa State University Press.

Koesdarto, S., Subekti, S., Studiawan, H. 2001. Model Pengendalian Siklus Infeksi Toxocariasis Sapi Dengan Fraksinasi Minyak Atsiri Rimpang Temuireng 
(Curcuma Aeruginosa Roxb) di Pulau Madura. JPMC., 2, 114-122.

Kutdang, E.T., Bukbuk, D.N., Ajayi, J.A., 2010.

The Prevalence Of Intestinal Helminths Of

Dogs (Canis familaris) In Jos, Plateau State,

Nigeria. Res., 2(8), 51-56.

Murniati, Sudarnika, E., Ridwan, Y. 2016.

Prevalensi dan Faktor Risiko Infeksi

Toxocara Cati Pada Kucing Peliharaan di

Kota Bogor. J. Ked. Hewan, 10(2), 139-142.

Rinaldi, L., Levecke, B., Boscoa, A., Ianniello, D., Pepe, P., Charlier, J., Cringolia, G., Vercruyss, J. 2014. Comparison Of Individual And Pooled Faecal Samples In Sheep For The Assessment Of Gastrointestinal Strongyle Infection And Anthelmintic Drug Efficacy Using Mcmaster And Mini-Flotac. Vet. Parasitol., 6(11), 1-8.

Sariego, I., Kirezi, K., Lázara, R., Niko, S., Katja, P., Fidel, A. 2012. Toxocariasis In Cuba: A Literature Review. PMC J., 6(2), 17.

Subronto. 2006. Infeksi Parasit dan Mikroba Pada Anjing Dan Kucing. Yogyakarta: Gadjah Mada University Press.

Sudhaus, W., Fitch, D. 2001. Comparative Studies On The Phylogeny And Systematics Of The Rhabditidae (Nematoda). J. Nematol, 33, 1-70.
Supraptini, J. 2013. Kasus Toxocariasis Pada Anjing Di Rumah Sakit Hewan Pendidikan Universitas Airlangga. Media Vetmedika J. Klin. Vet., 2(1), 18-24.

Suroiyah, F.A., Hastutiek, P., Yudhana, A., Sunarso, A., Purnama, M.T.E., Praja, R.N. 2018. Prevalensi Infeksi Toxocara Cati pada Kucing Peliharaan di Kecamatan Banyuwangi. J. Med. Vet., 1(3), 99-104.

Taniawati, S., Margono, S. 2008. Epidemiologi Soil Transmited Helminths. Dalam: Parasitologi Kedokteran. Edisi 4. Jakarta: Balai Penerbit Fkui.

Wichit, R., Chaisiri, K., Mahittikorn, A., Pubampen, S., Sanguankiat, S., Kusolsuk, T., Maipanich, W., Udonsom, R., Mori, H. 2014. Gastrointestinal Parasites Of Dogs And Cats In A Refuge In Nakhon Nayok, Thailand. J. Trop. Med. Parasitol., 38, 17-24.

Zelalem, G., Addis, M. 2012. Prevalence Of Gastrointestinal Helminthes Among Dogs In Bahir Dar Town, Ethiopia. World App. Sci. J., 19(5), 595-601. 